\title{
Sharp Expansion of Intensive Groundwater Irrigation, Semi-Arid Environment at the Northern Bekaa Valley Lebanon
}

\author{
Ihab Jomaa', Myriam Saadė Sbeih ${ }^{2}$, Ronald Jaubert ${ }^{2}$ \\ ${ }^{1}$ Department of Irrigation and Agrometeorology, Lebanese Agriculture Research Institute, Zahle, Lebanon \\ ${ }^{2}$ Graduate Institute of Geneva, Geneva, Switzerland \\ Email: ijomaa@lari.gov.lb
}

Received 28 February 2015; accepted 5 June 2015; published 8 June 2015

Copyright (C) 2015 by authors and Scientific Research Publishing Inc.

This work is licensed under the Creative Commons Attribution International License (CC BY). http://creativecommons.org/licenses/by/4.0/

(c) (i) Open Access

\section{Abstract}

This research focuses on the sharp expansion of groundwater irrigation in the Northern Beqaa, using Landsat satellite images and other auxiliary GIS relevant data sources. Topographic maps were used to assess the location and size of the irrigated area in the early 1960s as the initial years of agriculture expansion analysis. The first available Landsat image of the area was of the year 1972 followed with a series of accessible Landsat images until 2009. In the 1960s, agricultural practices were only limited to areas of surface water resources and open channels next to urban settlements. In the Early 1980s, farmers discovered the agricultural potential of the area. Only 3\% of the area was cultivated before the 1970s. The cultivated area reached about the $20 \%$ in late $1990 \mathrm{~s}$. Weather conditions, shallowness of groundwater tables, low fuel costs and market opportunities have led to an agricultural boom in the area considered as prone to desertification and of low productivity by national authorities. The area is however poorly understood from its hydro geological characteristics and exposed to intensive and unsustainable use of its natural resources.

\section{Keywords}

Northern Bekaa, Agriculture Expansion, Landsat, NDVI, Surface Irrigation, Surface Water Sources, Groundwater

\section{Introduction}

In Lebanon, agriculture is trapped between four chief facts: a geographically small country, diversity in climate and terrains, soil types and national and regional political instability. The high Mount-Lebanon chain blocks the 
Mediterranean climate from reaching inland areas. Relatively separated from the direct sea influence, the Bekaa Valley is by itself widely diverse in climate and land characteristics. Precipitation starts with about $800 \mathrm{~mm}$ to the south of the valley and it reaches less than $200 \mathrm{~mm}$ throughout its north. At the northern part of the Bekaa Valley, the Orontes River Watershed is, the zone of interest in this research, characterized by a low rainfall rate ranging between $300 \mathrm{~mm}$ to the south and $100 \mathrm{~mm}$ to the north.

The northern Bekaa Valley was always seen suitable for semi-arid climate crops [1]. Intensive agriculture in the semi-arid zone of the Bekaa was rarely investigated and it was thought to face salinity problems [2]. The National Action Plan to combat desertification classifies the Northern part of the Bekaa Valley as the most prone area to desertification [3].

The northern Bekaa Valley is generally considered as a marginal agriculture production area. Sanlaville (1963) described the Northern Bekaa as bare and sterile. Low precipitation rates because those rainfed cultivations succeed in only one out of five years. While the central Bekaa Valley was densely cultivated, in the northern part of the Bekaa cultivation was limited to small patches of land. Northern Bekaa was cultivated in only $10 \%$ of its cultivable area [4]. In the 1960s, irrigation in the Northern Bekaa was located in oases. At that time, three oases were found in the area: Laboue and El-Kaa-oases, feed from the Laboue water source, and Hermel oasis that gets water from nearby springs. Next-by populated areas, Hermel and El-Kaa oases were mainly cultivated by fruit trees and orchards (Figure 1) [4]. Poorly populated, in the sixties, villages of the Orontes River Watershed were considered as summer homes with only the main villages remaining populated during wintertime.

Since the 1980s, the Northern Bekaa is witnessing a rapid expansion of irrigated farming because of many local and regional factors. Urbanization increased because of the Lebanese internal unstable situation from the mid-seventies to late nineties. Regionally, the hard episodes in Iraq of the early 1990s stimulated agricultural exports from Lebanon as a response to the increasing demand.

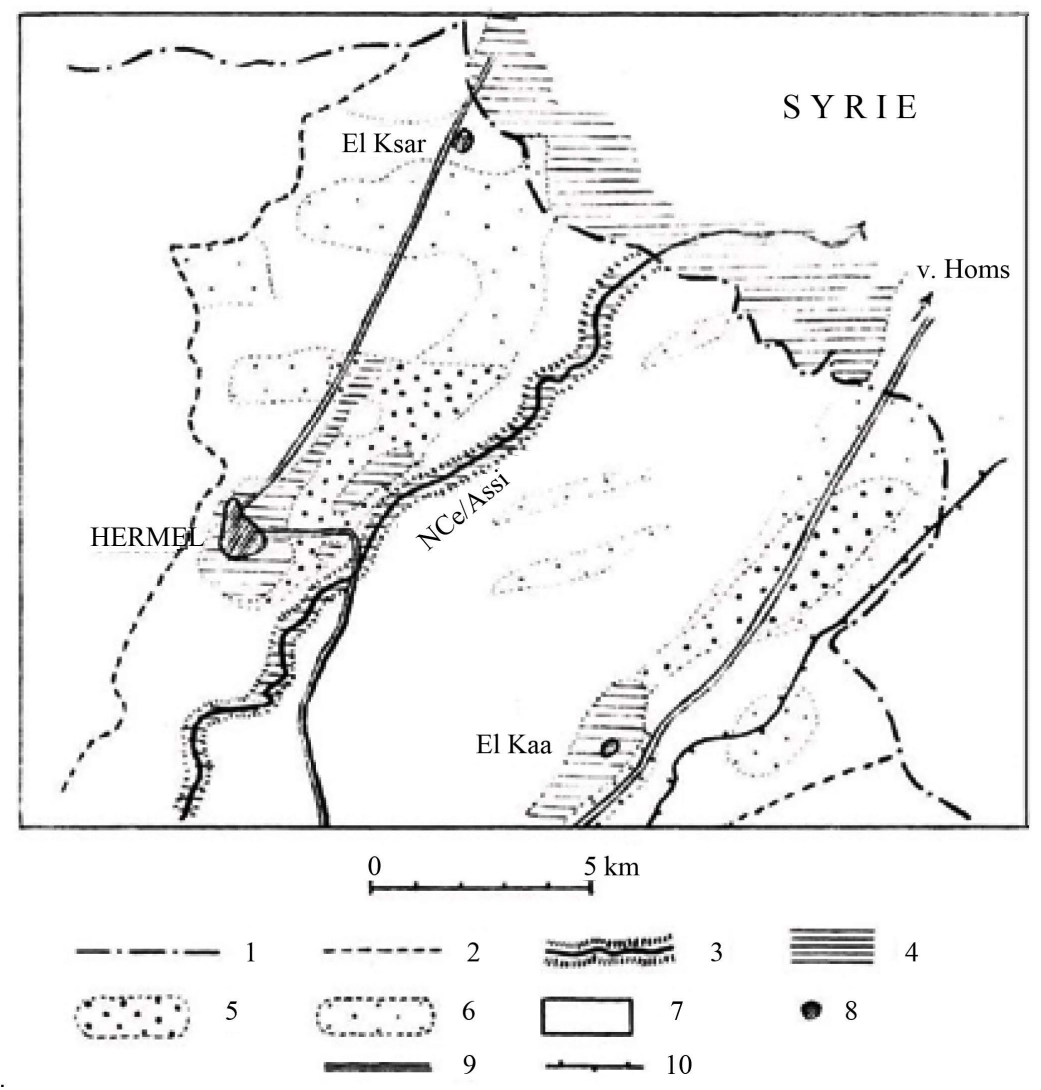

Figure 1. Agricultural map of 1963 for Hermel-El Kaa area [4]. 1: Lebanese-Syrian border; 2: External limits of the plain; 3: Steep valley; 4: Irrigated annual crops and orchards; 5: Poorly irrigated annual crops; 6: Rainfed crops and fallow; 7: Rangelands/Extensive pastures; 8: Localities; 9: Roads; 10: Railways. 
In the 1980s, farmers were spotting land suitable for agriculture-production in the Northern Bekaa where groundwater is easily accessible for irrigation purposes. New irrigated plots were brought under cultivation year after year even if sometimes-hard land-reclamations and rehabilitations were first required. Vegetables and new fruit trees varieties were introduced for the local and regional market. Watermelon was among the first vegetables that has proclaimed the area as potentially capable for large agriculture investments. The high land productivity was a major characteristic that it was added to the possibility to produce crops earlier in the season because of the specific weather conditions of the Northern Bekaa. The main elements of land-productivity were the climate, high fertilizer application rates and water availability. Although soils have in most cases a petrocalcic horizon, farmers broke through this horizon and rock pieces were excavated outside to the border of the farmland [5]. Once cleared, these soils became highly productive putting soils however under intensive cultivation regimes.

Groundwater is the main source of water for irrigation in the majority of the newly cultivated land-patches. In few places located close to the river, farmers were using water directly from the Assy River. The amount of groundwater surface water used for irrigation remains among the farmers' secrets where the water use efficiency is considered relatively low. Although drip irrigation is the most widely used water saving system in groundwater pumping areas, the farmers' knowledge of water requirements is considered way off the actual crop water requirement.

Although future scenarios consider the Northern Bekaa an area prone to desertification, it is attracting large agriculture investments at the risk of overexploitation ground water resources. The yearly expansion of irrigation-needs to be monitored for the sake of future water and land management in the Northern Bekaa. The present study provides a temporal and spatial analysis of the expansion of irrigated lands in the Northern Bekaa.

\section{Materials and Methods}

In Lebanon, the Orontes River Watershed of the Northern Bekaa has witnessed major expansion in irrigated agriculture lands and important changes in crop patterns. The watershed covers $13 \%$ of the total Lebanese territory or about 138,400 ha and it is located at the far north eastern part of the country to the border with Syria between $36^{\circ} 10^{\prime} \mathrm{E}$ to $36^{\circ} 36^{\prime} \mathrm{E}$ and $34^{\circ} 0^{\prime} \mathrm{N}$ to $34^{\circ} 29^{\prime} \mathrm{N}$ (Figure 2). Precipitation decreases gradually northward, reaching a rate of less than $200 \mathrm{~mm} /$ year at Hermel-El Kaa zone [6]. The population of the watershed reached about 58,000 inhabitants in 1994 (Shema de direction de la territoire Libanais), where it was about 8000 inhabitants in the 1960s [4]. Following the 1/20,000 scale topographic map of 1960s, the cultivated area was about $4600 \mathrm{ha}$, matching what it was mentioned by Sanlaville. The majority of the cultivated area was dedicated to fruit trees he nearby of the populated agglomerations with a large area of old traditional vineyards agricultural systems.

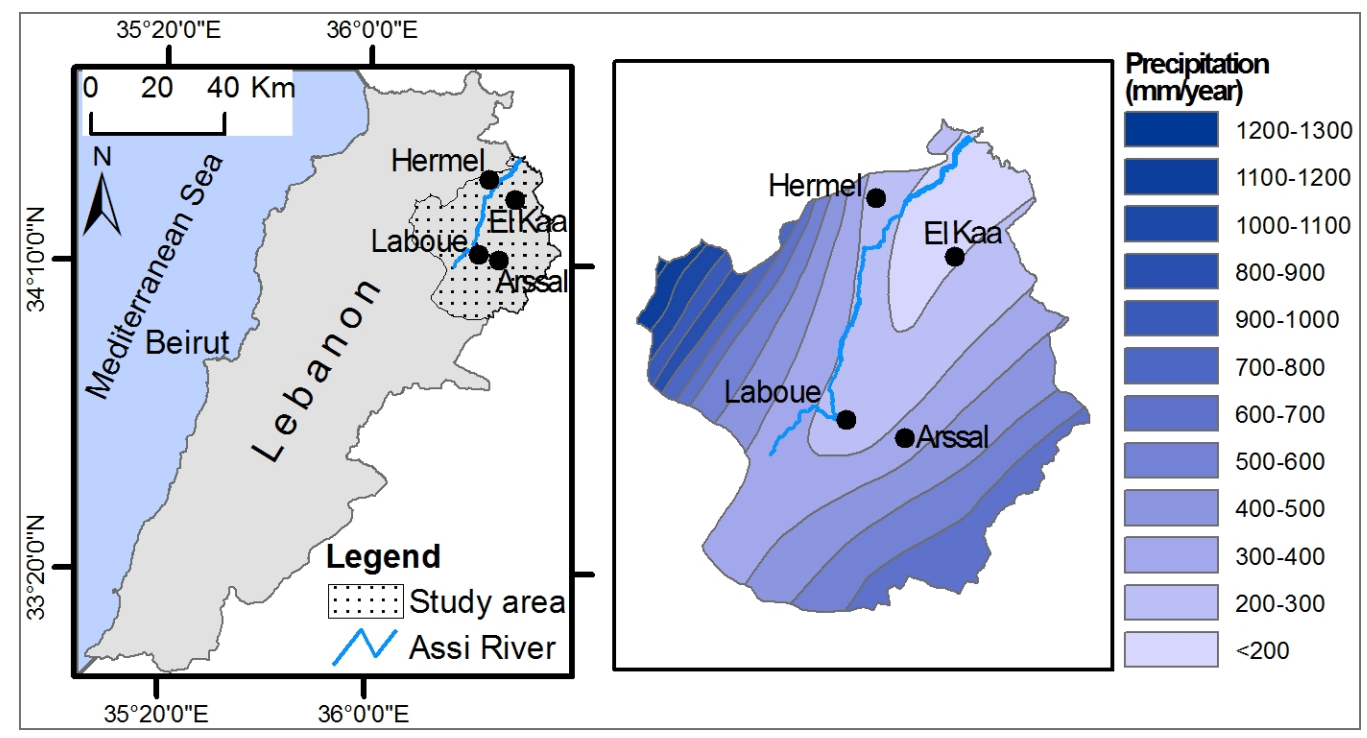

Figure 2. Study area and precipitation distribution. 


\section{Data Preparation and Extraction}

The topographic maps of 1/20,000 scale were used to extract cultivated land spots of the year 1962 (Figure 3). These maps were first geo referenced, according to Lambert Conformal Conic projection that appears on the maps. The cultivated areas were then digitized in a GIS environment into vector formats. The maps describe the land cover of the area, where the vineyard and fruit-orchards were visually spotted and delineated. The areas cultivated lands in 1962 were compared to another source of data of the same year, which is the agriculture areas map of Lebanon [7].

Landsat images were used for monitoring purposes and to determine the evolution of agricultural lands. The multispectral satellite images-data set were of Landsat Multispectral Scanner (MSS), Thematic Mapper (TM), and the Enhanced Thematic Mapper (ETM). The images acquisition date starts from 1972 and continue following the data availability and their importance for the purpose of the study analysis (Table 1). The satellite images were cropped fitting the watershed boarders that it helps in comparing results on a time series analysis. NDVI (Normalized Difference Vegetation Index) was generated for each image using GIS tools of ArcGIS software.

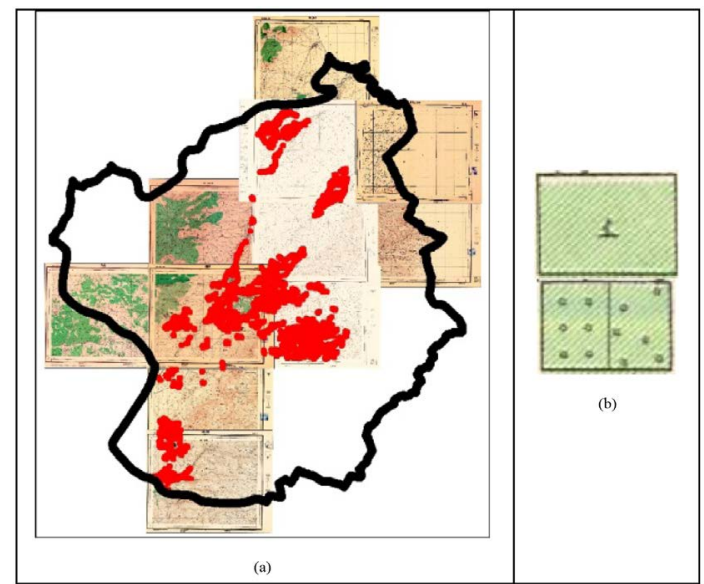

Figure 3. Topographic maps of the Orontes River Watershed; the legend of the vineyards on top and other fruit orchard in bottom.

Table 1. Satellite images acquisition dates.

\begin{tabular}{ccc}
\hline Image/year & Month \\
\hline Landsat MSS, 1972 & Sept, 15 \\
Landsat 5, 1984 & Aug, 5 \\
Landsat 5, 1987 & May, 26 \\
Landsat 4, 1988 & May, 20 \\
Landsat 4, 1989 & Aug, 27 \\
Landsat 4, 1990 & Aug, 30 \\
Landsat 5, 1991 & May, 21 \\
Landsat 4, 1992 & Aug, 3 \\
Landsat 5, 1997 & Sept \\
Landsat 5, 2000 & Oct, 04 \\
Landsat 5, 2002 & June, 20 \\
Landsat 5, 2003 & June, 23 \\
Landsat 5, 2006 & Sept, 19 \\
Landsat 5, 2007 & Sept, 07 \\
Landsat 5, 2009 & Sept, 27
\end{tabular}


The MSS Landsat satellite image of 1972 has a spatial resolution of $80 \times 80 \mathrm{~m}$ whereas all other images are of $30 \mathrm{~m}$ resolution. Other Landsat images, from 1984 to 2009, are of $30 \times 30 \mathrm{~m}$ spatial resolution. NDVI images were differentiated on a year-to-year sequence. The NDVI image of the year 1972 was directly subtracted from the NDVI image of the year 1984, i.e., the available consecutive year. Whenever vegetation is found on the image of the year 1972, the number will be between 0.2 and 0.45 (highest positive number obtained on 1972 NDVI image). If the vegetation spot was faded out during the available consecutive year, the number will be less than -0.1 , i.e., highly negative value. Therefore, a positive value in the NDVI image of the year 1972 will be subtracted from a negative value at the consecutive year, which will be added as another positive number. The obtained image will have a highly positive value on the places of vegetation degradation and a highly negative value whenever vegetation appears newly (or on the newer image date). In other words, we are searching a year-to-year vegetation changes on the level of cultivated land spots.

\section{Results and Discussions}

\subsection{Agriculture Lands since 1962}

The cultivated area in 1962 appeared to cover less than 4\% of the Orontes Watershed area. Orchards extended on most of the land nearby the village of El Kaa [8]. Vineyards were concentrated mainly in the area between the villages of Laboue and Aarsal, i.e., to the east of the main road that passes into Laboue (Figures 4(a)-(b)). The village of Laboue had a large area of fruit trees orchards, especially toward the western side of the same highway. This area is a quaternary soil deposit of low elevation in comparison to the area located to the east of the road. The difference in elevation exceeds $200 \mathrm{~m}$ within a distance of $500 \mathrm{~m}$. The surface water from the nearby water sources is easily delivered by gravity throughout the lowland valley to the western side of the highway, allowing farmers to produce high value crops, mainly apricot trees.

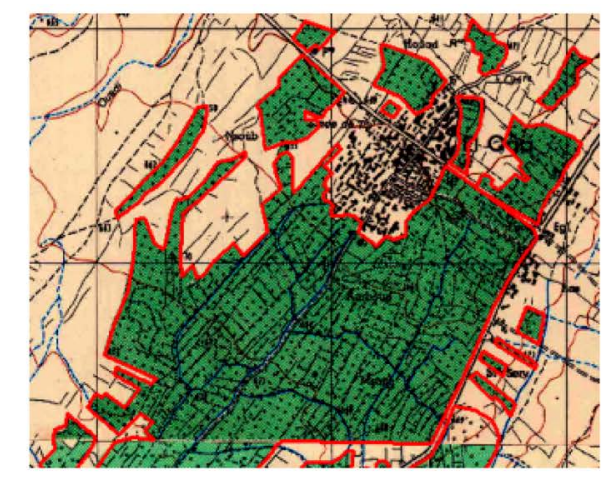

(a)

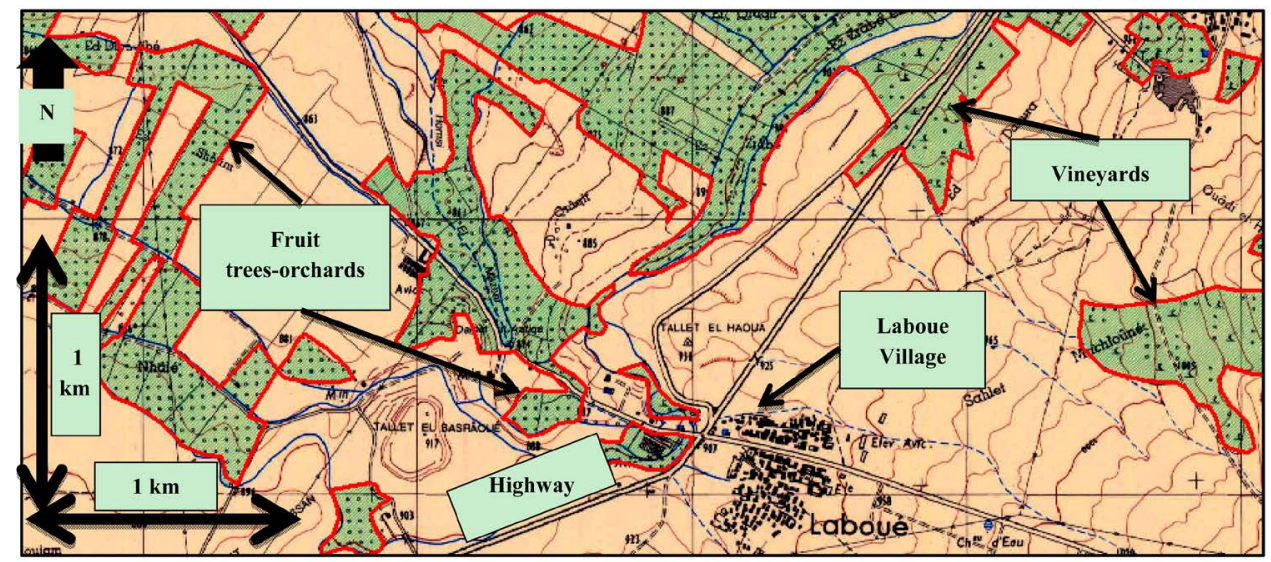

(b)

Figure 4. (a) El Kaa village the orchards at the surrounding; (b) the Laboue village and the nearby cultivated lands of the year 1962. 
The Landsat image of the year 1972 showed a similar distribution of cultivated lands in comparison to topographic maps of the year 1962 (Figure 5). Although the 1972 satellite image is of coarse spatial resolution, it is visually clear where cultivated lands are concentrated. It is important to note that some cultivation lands have appeared on the 1972 image at the Maharii El Kaa zone, when compared to the topographic maps cultivation places.

\subsection{Agriculture Lands after 1972}

The NDVIs images of the consecutively available years have demonstrated important changes following the time series (Figure 6).

NDVI images show significant changes in comparison to the year 1984 NDVI (Figure 7). There was almost a complete abandonment of the cultivated lands nearby El Kaa village. On the other hand, there was a boom of cultivated parcels that appeared at the Masharii El Kaa area. Sanlaville (1963) mentions first deep wells at the central Bekaa by the year 1955, where people of the northern Bekaa mentions that first deep well was drilled around the 1969 in the area of Mashari El Kaa.

The difference between consecutive NDVI images helped in locating important changes in land cover (Figure 8). Subtracting NDVI of 1972 out of the NDVI of the year 1984 showed white areas in places where vegetation has receded or disappeared. Areas where vegetation has expanded in 1984 appear in black in the subtracted NDVI image.

The area of El Masharii-El Kaa has demonstrated more than 100\% increase in cultivated lands when comparison is made between early eighties and the year 2009 (Figure 9). The NDVI images differentiation shows that irrigated plots have expanded on various locations throughout the watershed of the Orontes River. The expansion took place in locations that are far from surface water sources such as between Hermel and El Kaa villages North of Laboue village and to the east of Ras-Baalbeck village, cultivated lands are also expending were there are already important number of parcels appeared in this location. The total irrigated area reached about $19 \%$ of the total watershed area in 2009.

Once considered prone to desertification, the semiarid northern part of the Bekaa is witnessing consistent increase in irrigated lands. Development of wells excavation technologies opened the road for large investments in intensive irrigated agriculture. The relatively low cost of water pumps allows having complete set of equipped water-wells with minimum expenses. Adding, the shallow water table of the Masharii El Kaa, as an example, caused farmers to produce with lower costs. In the 1990s, the combination of shallow groundwater, low fuel prices and the highly suitable weather for cultivation attracted investors to implement large farmlands to produce vegetables and new fruit trees varieties. The area has the potential to produce earlier crops in comparison to

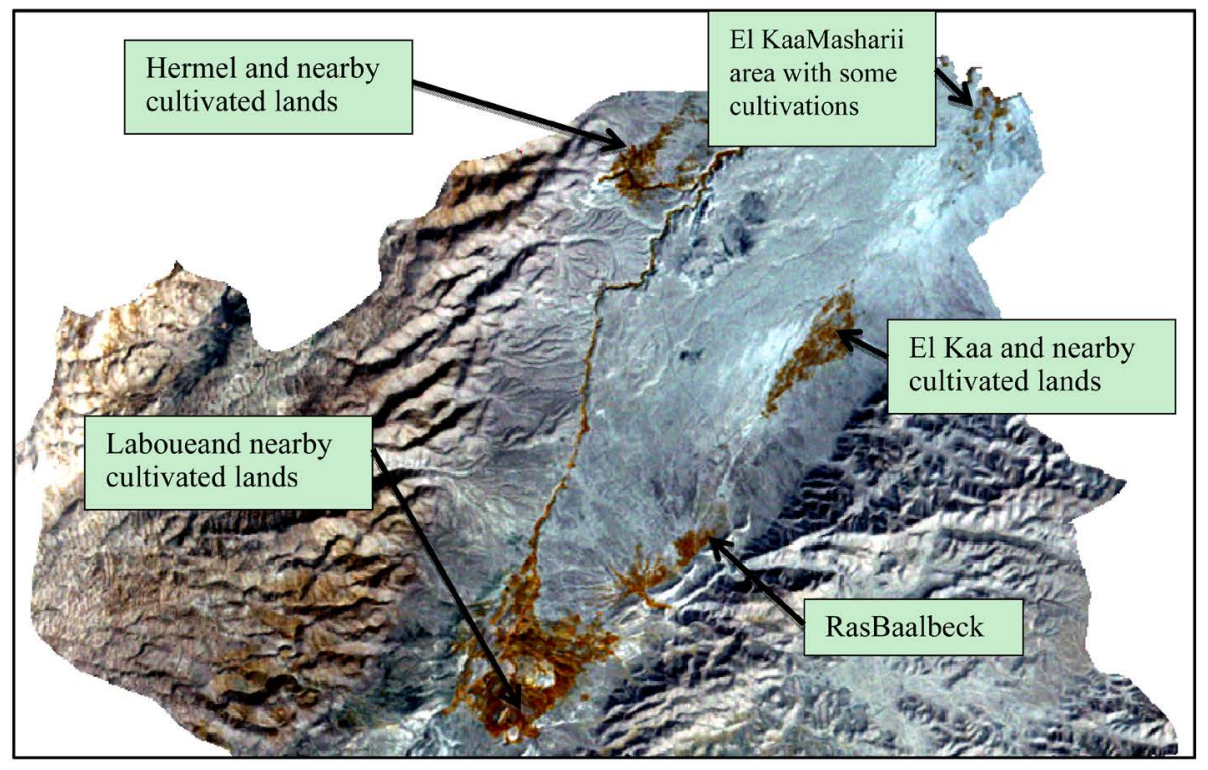

Figure 5. Landsat image of the year 1972 (band combination $R=4, G=3$ and $B=2$ ). 
I. Jomaa et al.
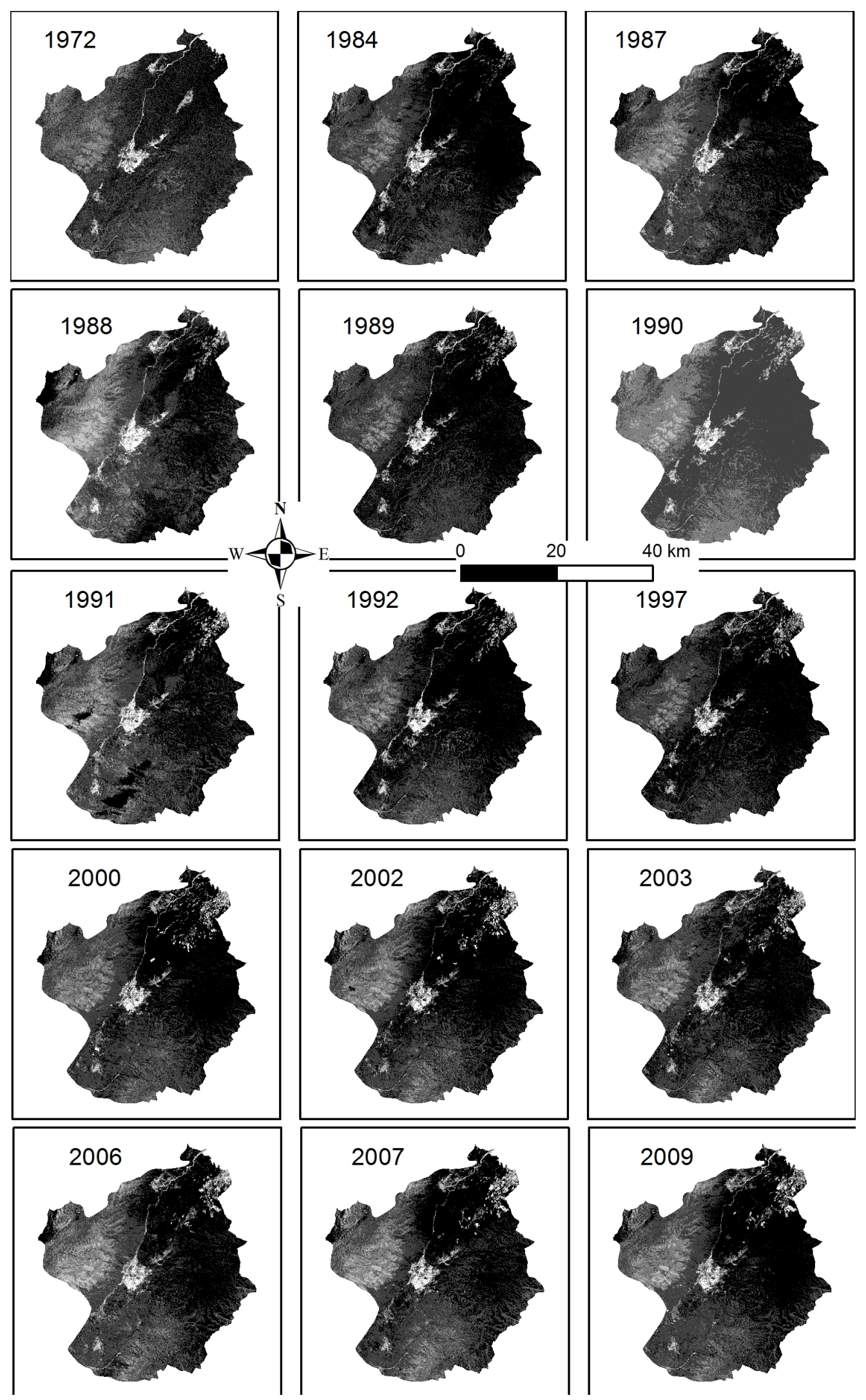

Figure 6. NDVI images of available time series. 


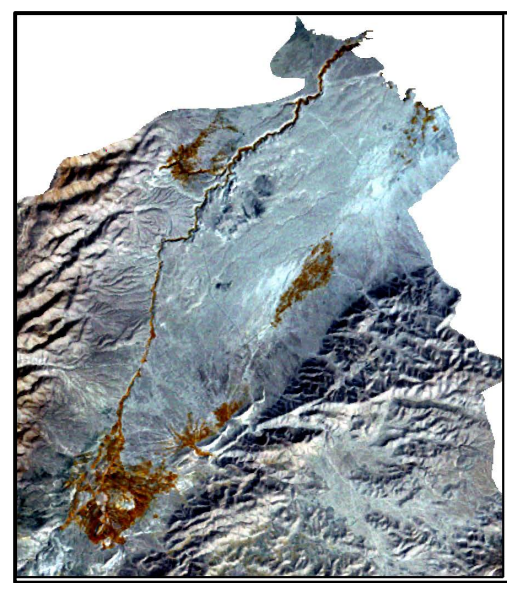

(a)

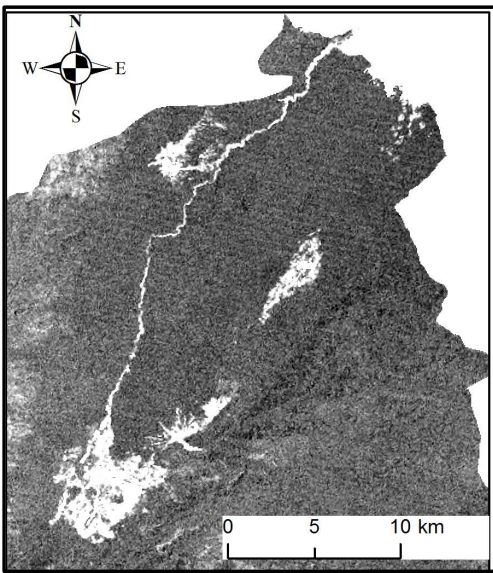

(c)

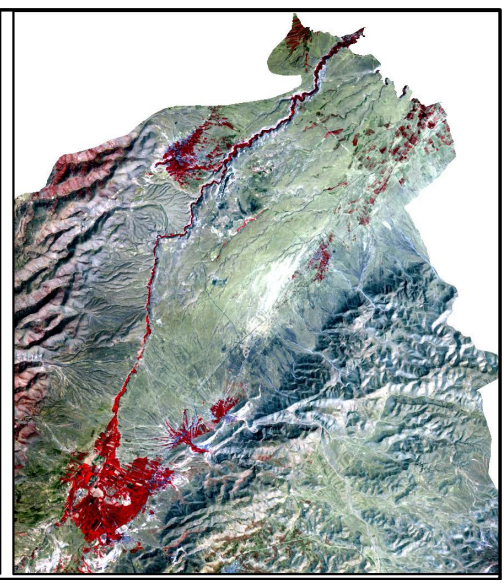

(b)

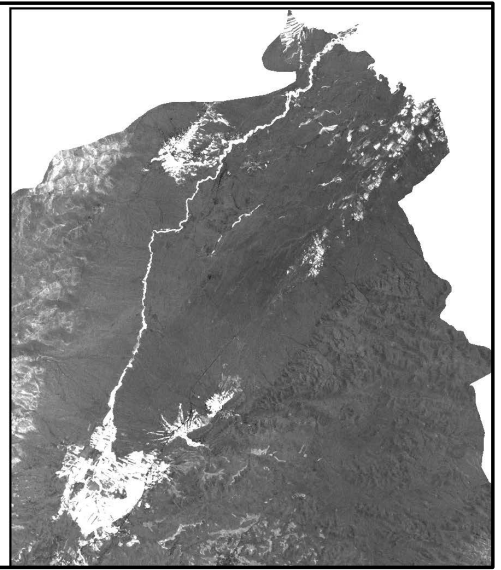

(d)

Figure 7. Landsat image of the year 1972 (a); Landsat image of the year 1984 (b); NDVI 1972 (c); NDVI 1984 (d). Blue circle represents the comparison the El Masharia area of El Kaa; Red circle represents the cultivated lands at the nearby El Kaa village.

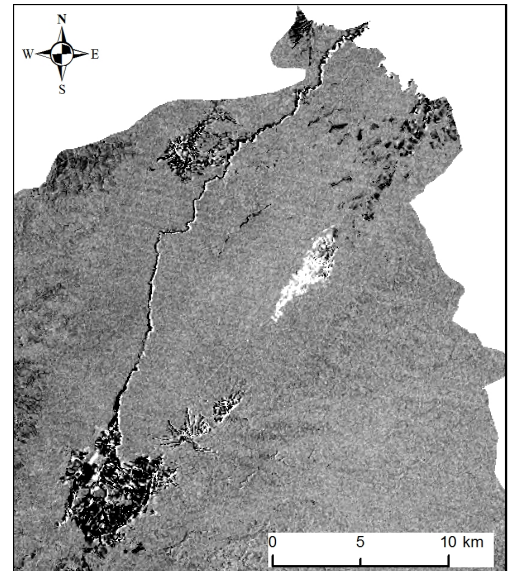

(a)

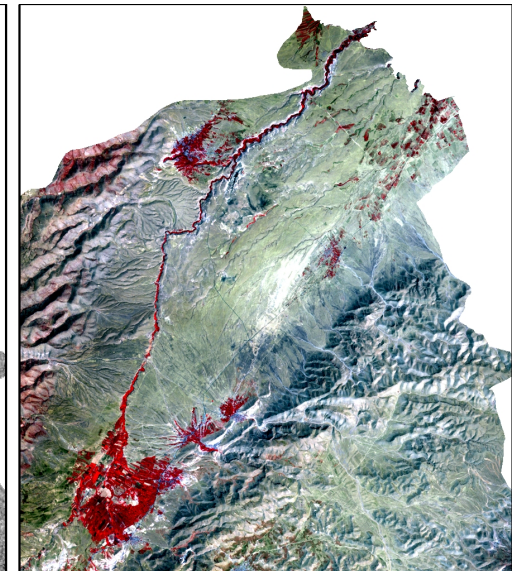

(b)

Figure 8. NDVI 1972 subtracted from NDVI 1984 (a); Landsat image of the 1984 (b). Blue circle represents the comparison the El Masharia area of El Kaa; Red circle represents the cultivated lands at the nearby El Kaa village. 


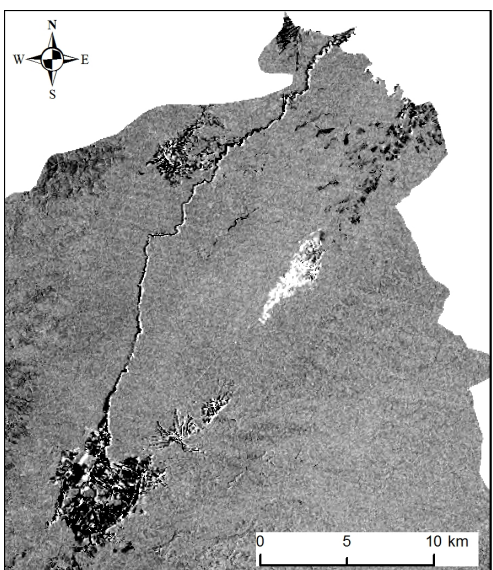

(a)

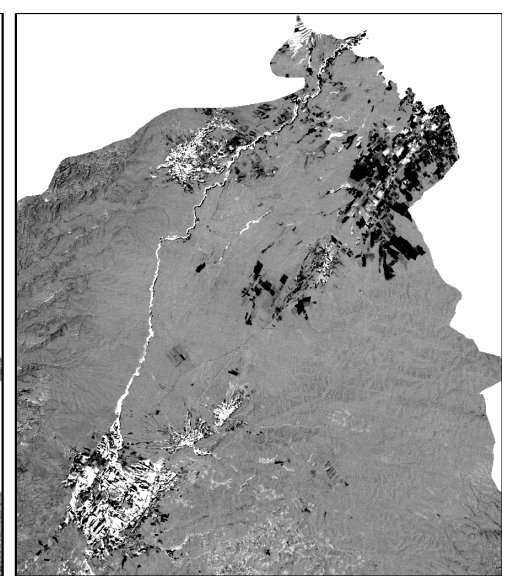

(b)

Figure 9. NDVI 1972 subtracted from NDVI 1984 (a); NDVI 1984 subtracted from NDVI 2009 (b). Blue circle represents the comparison the El Masharia area of El Kaa; Red circle represents the cultivated lands at the nearby El Kaa village.

other location in Lebanon, which raise the competiveness of the northern Bekaa. However, it is worth re-noting that intensive irrigation in this semi-arid environment is water demanding and might lead to rapid land degradation and salinization.

At governmental level, the northern Bekaa is still considered as a low productivy area. Although Ministry of Agriculture is calling for rainfed forage crops such as barley and low water requirement fruit tree crops such as olives, farmers are investing in intensive irrigated agriculture. As already mentioned, the local market absorbs the early produced crops of northern Bekaa. Located on the border with Syria, farmers had, before the conflict in the country, an easy to Arab countries like Iraq. In the early 1990s, the boom of intensive cultivation, in the northern Bekaa, coincided with the end of the civil war in Lebanon and the beginning of first gulf war in which severely affected agriculture in Iraq. This was the golden era of intensive agriculture in the northern Bekaa.

Intensive irrigated agriculture is still expanding in the northern Bekaa and future scenarios have yet to be drawn. In comparison to the early days of the expansion era, fuel prices have doubled, groundwater is dropping in depth on a yearly basis, and lands are set under unsustainable management where neighboring Arab countries are becoming producers to supply their domestic markets. All these parameters have to consider in order figuring out possible future scenarios for the area.

\section{Conclusions}

The early 1970s irrigated lands of the northern Bekaa were mainly concentrated in areas next to open water channels and areas of the surface water availability. Irrigated plots were mainly located near springs and humanmade channels. Vineyards were the main crops that were grown in areas far from an existing surface water sources. Fruit trees were largely grown on irrigated surfaces where flood irrigation is being practiced. It should also be noted that urban expansion was limited which might also be reflected on the narrowness in cultivated lands. Petrocalcic soils of the area have added another limiting factor against the expansion of agriculture lands.

The multiplication of wells and the development of groundwater extraction in the 1980's have changed the spatial patterns of water uses and new agricultural practices have immerged. Extensive agriculture areas were changed to intensively irrigated land. Farmers are investing in land that can be irrigated from groundwater for developing intensive agriculture projects.

The northern Bekaa is officially regarded as a dry low agricultural productivity areaprone to desertification. Farmers discovered the agricultural potentiality of the area where they found suitable productive parameters: favorable weather for early production, shallow groundwater table, low fuel cost and access tolocal and international markets. Whenever these producing factors exist, farmers are willing to dig for other land patches for agricultural purposes throughout the northern Bekaa.

Future trends and scenarios have to be built in order to investigate the agriculture potentiality and its negative/ 
positive trend at the northern Bekaa. In a semiarid environment, intensive agriculture may lead to severe soil degradation. Intensive exploitation could cause relatively rapid depletion groundwater resources. Groundwater is extracted on an individual basis, in absence of monitoring and of an overall water use strategy.

Although the northern Bekaa has demonstrated a large agricultural potential in the short term, the sustainability of the current intensive agricultural production system is questionable. Appropriate water management strategies and higher irrigation water use efficiency will secure the productive sustainability of the northern Bekaa Valley.

\section{Acknowledgements}

This paper is made possible as part of the project entitled "Irrigation Water Managements in the Bekaa Valley, Lebanon" supported by Global Program Water Initiatives of the Swiss Agency for Development and Cooperation.

\section{References}

[1] Yau, S.K., Ryan, J., Pala, M., Nimah, M. and Nassar, A. (2004) Common Vetch in Rotation with Barley: A Sustainable Farming System for a Cool, Semi-Arid Mediterranean Area. Australian Agronomy Conference 2004, 12th AAC, 4th ICSC.

[2] Darwish, T., Atallah, T., El Moujabber, M. and Khatib, N. (2005) Salinity Evolution and Crop Response to Secondary Soil Salinity in Two Agro-Climatic Zones in Lebanon. Agriculture Water Management, 78, 152-164. http://dx.doi.org/10.1016/j.agwat.2005.04.020

[3] http://www.codel-lb.org/

[4] Paul. S. (1963) Les régions agricoles du Liban. Revue de géographie de Lyon, 38, 47-90.

[5] Darwish, T., Jomaa, I., Others (2006) Soil Map of Lebanon at 1/50000. CNRS, Lebanon.

[6] Plassard, J. (1971) Carte pluviométrique du Liban à l'échelle de $1 / 2^{00.000 e}$. République Libanaise. Ministère des travaux publics. Direction Générale de l'Aviation Civile.

[7] Boulos, F.B. (1963) Carte agricole du Liban avec divers aspects météorologique, touristique, administratif et social. Conseil National de la Recherche Scientifique, Liban. 3eme Edition 1980.

[8] Jacques, G. Aspect général de l'agriculture libanaise: Tome I: Les circonscriptions foncières et la propriété. Tome II: Les régions agricoles et les principales cultures. Tome III: Enquête sur la bande côtière: Région agrumes-bananes. Rapport présenté au Ministère de l’Agriculture de la République Libanaise, Service Statistique, Beyrouth, 1960-1961. 